\title{
ARTI PENTING SITUS-SITUS PELABUHAN KUNA DI KARAWANG, JAWA BARAT, SEBAGAI JALUR TRANSPORTASI ${ }^{1}$ \\ The Significance of Ancient Port Sites in Karawang as Transportation Routes in West Java
}

\author{
Libra Hari Inagurasi \\ Pusat Penelitian Arkeologi Nasional \\ Jalan Raya Condet Pejaten No. 4, Jakarta Selatan \\ E-mail: librainagurasi@yahoo.com \\ Naskah diterima redaksi: 19 November 2016 - Revisi terakhir: 23 Oktober 2016 \\ Naskah disetujui terbit: 28 November 2016
}

\begin{abstract}
Karawang is a district in West Java Province in which the river territory were continuously flowing and were identified as old Ci Tarum and Ci Lamaya which lies in the northern part of Java Sea. The Northern coast of Karawang has many gulf estuaries. The existence of port, rivers, and coastal areas in Karawang emerged in the $16^{\text {th }}$ century and in the $17^{\text {th }}$ century as well as on written documents of Portuguese sources, and also from those documents of Vereenigde Oost India Company (VOC). The Northern coast of Karawang were crowded by navigation of merchant ships and patrol boats. From those facts of course raises the question of where was these ports originated in Karawang. This study aimed to uncover, identify, ancient ports which was located on the northern coast of Karawang based on the written documents, archaeological remains, and its natural environment. By using surveys, interviews, the results of this research found out the significance of the ancient ports were located at the banks of the Ci Tarum, the banks of the mouth of a river in Pasir Putih, and Tangkolak River estuary. Those ports function for ships as it landed ashore and also as river transportation mode. Through these ports trading took place, the spread of Islam and also served as ships patrol. By searching through the names on the written documents, as well as ecological and remains, archaeological remains were found, some of which have been investigated functions as ancient ports which was mentioned by de Barros.
\end{abstract}

Keywords: the northern coast of western Java, Karawang, harbors, estuaries, rivers.

\begin{abstract}
Abstrak
Karawang, kabupaten di Provinsi Jawa Barat, wilayahnya dialiri sungai-sungai besar tergolong stadia tua, seperti Ci Tarum dan Ci Lamaya, Laut Jawa terhampar di sebelah utaranya. Pesisir utara Karawang memiliki banyak muara sungai. Keberadaan pelabuhan, sungai, dan kawasan pesisir di Karawang muncul pada abad ke-16 dan abad ke-17 seperti yang terdapat pada sumber-sumber tertulis sumber Portugis, dan
\end{abstract}

1 Paper ini pernah dipresentasikan pada The $2^{\text {nd }}$ SEAMEO SPAFA International Conference on Southeast Asian Archaeology, Bangkok 30 May - 2 June 2016, dengan beberapa perubahan. 
Vereenigde Oostindische Compagnie (VOC). Pesisir utara Karawang ramai dilayari oleh kapal dagang dan kapal patroli. Tentu dari keterangan-keterangan tersebut menimbulkan pertanyaan di manakah pelabuhan-pelabuhan kuna tempat berlabuhnya kapal di Karawang. Tulisan ini bertujuan mengungkap, mengidentifikasi, pelabuhanpelabuhan kuna yang terdapat di pantai utara Karawang berdasarkan sumber tertulis, tinggalan arkeologi, dan lingkungan alam. Dengan menggunakan metode survei, wawancara, hasil dari penelitian ini adalah diketahuinya arti penting pelabuhanpelabuhan kuna di tepi Ci Tarum, tepi muara sungai di pantai Pasir Putih, dan muara Sungai Tangkolak. Pelabuhan-pelabuhan tersebut sebagai tempat merapatnya kapal dan jalur transportasi laut dan sungai. Melalui pelabuhan-pelabuhan berlangsung perdagangan, penyebaran Islam, dan juga kapal-kapal yang berpatroli. Mencermati nama-nama pada sumber tertulis, ekologi, dan tinggalan-tinggalan arkeologi yang ditemukan, beberapa pelabuhan yang telah diteliti diduga adalah pelabuhan kuna sebagaimana yang disebutkan oleh de Barros.

Kata kunci: pantai utara Jawa bagian barat, Karawang, pelabuhan, muara sungai, sungai.

\section{PENDAHULUAN}

Indonesia merupakan negara kepulauan, terdiri dari ribuan pulau, baik pulau besar maupun pulau kecil. Wilayah perairan lebih luas daripada wilayah daratan. Antara pulau satu dengan pulau lainnya dipisahkan oleh laut. Akan tetapi, laut juga menjadi penghubung di antara ribuan pulau. Memiliki wilayah perairan yang begitu luas sehingga Indonesia kemudian dikenal sebagai negara maritim. Wilayah perairan mencakup daerah-daerah yang berada di tepi aliran sungai, tepi muara sungai, pantai, dan juga danau. Wilayah tepi muara sungai dan pantai selanjunya disebut dengan wilayah pesisir. Tercatat wilayah-wilayah pesisir di kepulauan Indonesia. Sejak abad ke-13 dan abad-abad berikutnya telah tumbuh kota-kota sebagai pusat kerajaan-kerajaan dan juga kota pelabuhan. Sebagai contoh adalah Samudra Pasai, Jepara, Gresik Banten, Cirebon, Batavia, Makassar, dan Banjarmasin (Tjandrasasmita, 1990: 30, $125,128,147)$.
Di dalam tulisan ini diuraikan contoh, yakni Karawang, wilayah pesisir yang terdapat di Jawa Barat. Wilayah Kabupaten Karawang berada pada koordinat $07^{\circ} 02^{\prime}-$ $107^{\circ} 40^{\prime}$ BT dan $5^{\circ} 56^{\prime}-6^{\circ} 34^{\prime}$ LS. Letak geografis Karawang berada di pantai utara Pulau Jawa bagian barat. Batasbatas Kabupaten Karawang, sebelah barat Kabupaten Bekasi, utara Laut Jawa, timur Kabupaten Subang, selatan Kabupaten Bogor, dan Kabupaten Cianjur. Bentang alam Karawang, secara umum terdiri dari pantai, dataran rendah, perbukitan, dan pegunungan. Pantai dan dataran rendah berada di bagian utara, perbukitan di bagian tengah, dan gunung di bagian selatan (Tim Penelitian, 2015: 6).

Penelitian dan tulisan tentang Karawang yang sudah ada pada umumnya tentangkompleks percandian Batujayadan Cibuaya. Pusat Arkeologi Nasional telah melakukan penelitian di Karawang tahun 2009, 2011, 2013, dan 2015. Penelitian tahun 2009 dikoordinasi oleh Agustijanto Indradjaya difokuskan pada artefak 
tembikar dan garis pantai (Tim Penyusun, 2009: 61-113). Penelitian tahun 2011 yang di koordinasi oleh Titi Surti Nastiti melakukan eksplorasi potensi arkeologi di Kabupaten Bekasi dan Kabupaten Karawang. Potensi tinggalan arkeologi di Kabupaten Karawang beragam mulai dari masa Prasejarah sampai masa Kolonial (Nastiti dkk., 2011). Penelitian yang dikoordinasi oleh Libra Hari Inagurasi pada tahun 2013, memfokuskan perhatian pada pantai dan sungai-sungai besar di Karawang (Inagurasi dkk., 2013: 39). Adapun penelitian tahun 2015 yang dikoordinasi oleh Truman Simanjuntak mengaplikasikan antara kegiatan pengumpulan data potensi arkeologi dengan kegiatan workshop, sehingga lebih tepat disebut workshop - penelitian arkeologi (Tim Penelitian, 2015: v). Hasan Djafar menyatakan bahwa kompleks percandian Batujaya yang terletak di aliran $\mathrm{Ci}$ Tarum, Karawang. Batujaya merupakan kompleks percandian agama Buddha tertua di Jawa dan dibangun pada masa Kerajaan Tarumanagara antara abad ke-6 sampai dengan abad ke-8. Bangunan percandian Batujaya memperlihatkan adanya kesamaan dengan ciri-ciri pada candi-candi yang terdapat di India Utara (Djafar, 2010: 127, 130).

Tulisan ini membahas situs-situs di wilayah perairan kaitannya dengan pelabuhan kuna di Karawang yang belum pernah dibahas. Meskipun penelitianpenelitian sebelumnya tidak meyinggung, namun dapat digunakan sebagai panduan untuk penelitian dengan tema pelabuhan kuna. Topik tentang pelabuhan kuna di Karawang penting, mengingat letak geografis wilayah Karawang berada di daerah pantai atau pesisir di tepi Laut
Jawa, bagian dari pantai utara Jawa bagian barat. Selain itu di Karawang mengalir sungai-sungai besar ke arah utara bermuara di Laut Jawa.

Menurut Trisulistyono yang dikutip oleh Pardjoko dan Utomo, wilayah pantai atau pesisir merupakan tempat atau pusat berlangsungnya tukar menukar atau keluar masuknya barang perdagangan antara daerah pedalaman dan daerah di luar wilayah (Pardjoko dan Utomo, 2013: 10). Penelitian situs-situs di wilayah perairan Karawang dilakukan dengan menggunakan metode survei untuk pengumpulan sejumlah data utama berupa data arkeologi dan data lain yang mendukung yakni lingkungan fisik, dan juga nama-nama tempat (toponimi). Pengamatan lingkungan fisik (ekologi) diperlukan dalam penelitian situs-situs di wilayah perairan. Keletakan pelabuhan atau dermaga sangat ditentukan oleh ekologi dengan syarat-syarat yang dapat mendukung berlabuhnya perahu atau merapatnya kapal. Selain survei untuk pengamatan data arkeologi dan ekologi,juga dilakukan wawancara untuk memperoleh informasi yang tidak didapatkan dari data arkeologi. Wawancara dilakukan dengan informan yang dipandang banyak memiliki informasi, ingatan, mengenai wilayah perairan di Karawang.

Adapun studi kepustakaan dilakukan sebelum penelitian lapangan untuk pengayaan mengenai pengetahuan lokasi penelitian dengan menelusuri hasil-hasil penelitian pada bidang ilmu tekait yang telah dilakukan sebelumnya, pengamatan peta, pemberitaan sumbersumber tertulis mengenai Karawang pada masa lampau, dan pemahaman mengenai konsep-konsep pelabuhan. Data yang 
telah terkumpul diolah, dideskripsi, dianalisis. Hasil analisis antara data yang satu dengan lainnya diintegrasikan kemudian diintepretasikan.

Tulisan ini bertujuan mengungkap, mengidentifikasi pelabuhan-pelabuhan kuna yang terdapat di Karawang pada masa lampau dan kondisi pada saat ini. Hasil yang diperoleh merupakan integrasi data arkeologi dan lingkungan fisik. Pelabuhan dalam tulisan ini dimaksudkan sebagai dermaga tempat berlabuh, persinggahan kapal atau perahu yang berada di wilayah perairan di antaranya laut, pantai, muara sungai, dan tepi sungai. Sehubungan dengan hal tersebut, sasaran yang hendak dicapai dalam penulisan ini adalah wilayah yang berada di pantai, muara sungai, dan tepi sungai, yang diduga sebagai lokasi pelabuhan masa lampau di Karawang.

Adapun permasalahan dirumuskan dengan pertanyaan-pertanyaan sebagai berikut. Di manakah lokasi pelabuhanpelabuhan kuna di Karawang? Faktorfaktor apa saja yang memengaruhi muncul dan tumbuhnya pelabuhan-pelabuhan di Karawang? Jenis tinggalan-tinggalan arkeologi yang masih dapat ditemukan meliputi apa saja, dan berasal dari periode kapan? Apakah antara pelabuhan satu dengan lainnya memiliki keterkaitan?

\section{HASIL DAN PEMBAHASAN}

\section{Situs-Situs di Tepi Ci Tarum}

\section{Situs Kedawung}

Situs Kedawung secara administratif termasuk wilayah Dusun Kedawung, Desa Tanjungbungin, Kecamatan Pakisjaya.
Tanjungbungin merupakan ujung barat pesisir utara Karawang. Lokasi berada di sebelah timur Ci Tarum berjarak $75 \mathrm{~m}$ dari sungai. Jarak antara Dusun Kedawung dengan muara $\mathrm{Ci}$ Tarum sekitar $2 \mathrm{~km}$. Ci Tarum merupakan batas alam memisahkan antara wilayah Kabupaten Bekasi di sebelah barat dan wilayah Kabupaten Karawang di sebelah timur aliran $\mathrm{Ci}$ Tarum. Bentang alam Desa Tanjungbungin merupakan dataran rendah di tepi aliran Ci Tarum. Saat ini Kedawung merupakan perkampungan yang padat penduduk. Mereka bermatapencaharian sebagai buruh, petani, pedagang, dan usaha jasa penyeberangan sampan atau perahu di Ci Tarum. Persawahan padi terdapat di sebelah timur dan selatan perkampungan.

Tinggalan-tinggalan arkeologi di Situs Kedawung meliputi bekas gudang garam, pecahan keramik asing, pecahan tembikar, pabean (duane), makam Cina. Bekas gudang garam terletak di sebelah timur Ci Tarum berjarak $20 \mathrm{~m}$, tepat di bawah tanggul sungai. Bekas gudang berupa sebuah bangunan panggung berdenah empat persegi panjang, pintu masuk gudang menghadap ke arah utara, bangunan ditopang oleh umpakumpak batu, lantai bangunan dibuat dari balok-balok kayu, dinding dibuat dari bilik bambu, atap berbentuk limas ditutup dengan genteng. Penjelasan yang diperoleh dari informan mantan Kepala Desa Tanjungbungin, Ahyar, dahulu gudang digunakan untuk menyimpan garam masa Kolonial Belanda. Saat ini bangunan bekas gudang difungsikan untuk SD Negeri Tanjungbungin. 
Duane yang dimaksudkan adalah pabean atau tempat syahbandar mengatur ke luar masuknya perahu atau sampan dan kapal pengangkut komoditas perdagangan dan memungut bea atau pajak atas komoditas tersebut. Bangunan duane terletak di seberang Kantor Kepala Desa Tanjungbungin, bersebelahan dengan Pasar Tanjungbungin. Saat ini sisa bangunan duane atau pabean yang masih bisa diamati berupa bangunan berdenah empat persegi panjang dinding dibuat dari bahan kayu digunakan untuk toko.

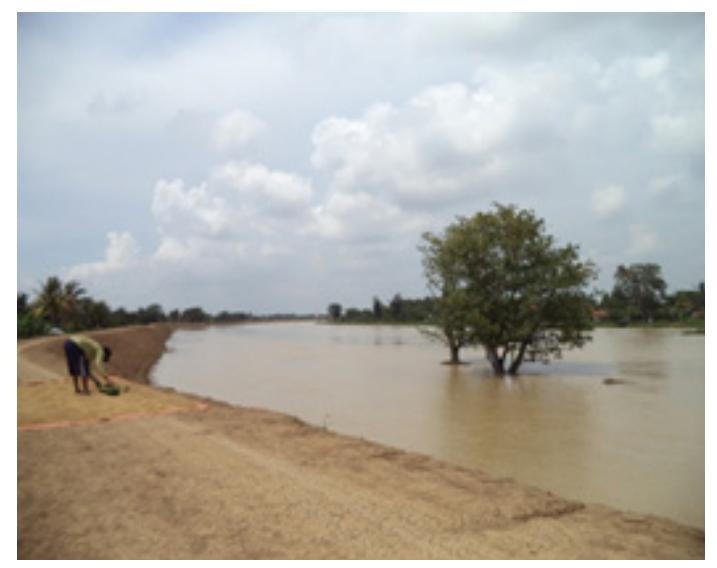

Gambar 1. Aliran Ci Tarum di Tanjungbungin. (Sumber: Dokumen Pusat Arkeologi Nasional, 2013)

Selain temuan arkeologi, di Situs Kedawung juga dijumpai toponimi, namanama tempat berkaitan dengan aktivitas jual beli dan keluar masuknya barang, di antaranya adalah pasar dan pabean (duane). Desa Tanjungbungin memiliki sebuah pasar yang keberadaannya sudah lama. Aktivitas jual beli di Pasar Tanjungbungin berlanjut hingga saat ini, berlangsung sekali dalam satu minggu pada Jumat. Pasar berada di sebelah utara bangunan bekas gudang berjarak kurang lebih $300 \mathrm{~m}$. Jenis-jenis komoditas yang diperdagangkan di antaranya beras, garam, sayur-mayur, ikan, kayu, dan pakaian.

\section{Situs Bunut}

Bunut nama sebuah dusun di Kelurahan Karawang Kulon, Kecamatan Karawang Barat. Situs Bunut termasuk wilayah Kota Karawang dengan populasi penduduk yang padat. Posisi situs berada sebelah timur di tepi Ci Tarum. Tinggalan arkeologi pada situs tersebut meliputi masjid, makam, dan mata uang. Masjid Agung Karawang berada di tengah Kota Karawang di sebelah barat alunalun, terletak di tepi Ci Tarum, memiliki riwayat cukup tua terletak. Menurut keterangan pengurus masjid, Dody Permana, awalnya masjid dibangun pada tahun $1418 \mathrm{M}$ (awal abad ke-15) oleh seorang ulama keturunan Arab bernama Syekh Quro. Nama asli Syekh Quro adalah Syekh Hasanuddin bin Syekh Yusuf Siddik. Masjid tersebut dikenal juga dengan nama Masjid Syekh Quro. Walaupun memiliki riwayat tua, namun masjid tidak terlihat lagi bangunan aslinya karena pemugaran beberapa kali.

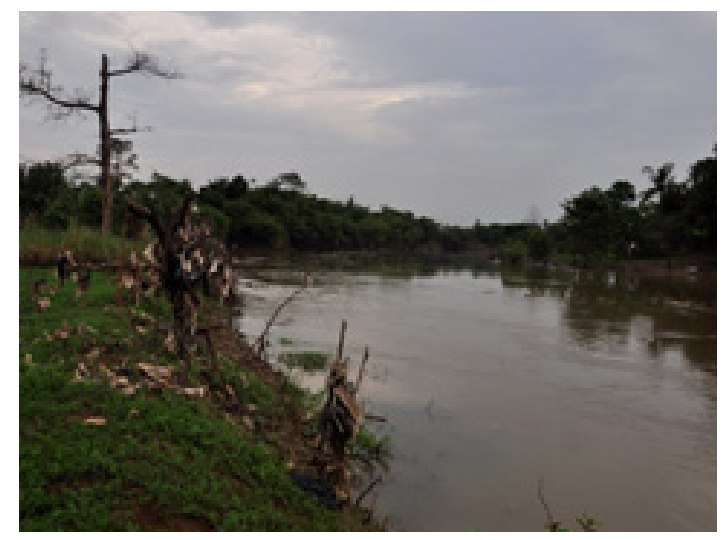

Gambar 2. Ci Tarum sebelah barat Masjid Agung Karawang (Masjid Syekh Quro). (Sumber: Dokumen Pusat Penelitan Arkeologi Nasional, 2013) 
Benda-benda kuna yang masih dapat ditemukan di masjid adalah umpak batu, balok-balok kayu bekas tiang-tiang masjid, tembikar bekas kemuncak atap masjid berbentuk mahkota, naskahnaskah kuna, dan miniatur masjid pada bentuk awal. Benda-benda tersebut memberikan informasi mengenai bahan dan denah masjid sebelumnya, denah asli masjid empat persegi panjang atap berbentuk limas. Kompleks makam terdapat di belakang masjid. Di antara makam-makam tersebut terdapat makam tua, yakni makam Syekh Quro dan para pengikut atau muridnya di antaranya adalah Ki Bunut. Keberadaan makam Syekh Quro pada masa kini tidak dapat diamati, diperkirakan telah tertutup tanah dan bangunan mesjid, ketika dilakukan pembangunan untuk perluasan masjid.

Mata uang yang ditemukan di Situs Bunut berasal dari tepi aliran Ci Tarum berupa mata uang logam VOC, Hindia Belanda, dan Arab masing-masing dibuat dari bahan perunggu, perak, dan tembaga. Pada mata uang VOC tertulis angka tahun masing-masing 1709, 1746, dan 1794. Adapun pada mata uang Belanda tertulis "WILHELMINA KONINGIN DER NEDERLANDEN" dan "MUNT VAN HET BKONINGRIJK DER NEDERLANDEN", bergambar mahkota serta angka tahun yang tertulis 1928 dan 1929.

\section{Situs Tanjungmekar}

Tanjungmekar nama sebuah dusun, Dusun Tanjungmekar, Kelurahan Tanjung Pura Kupoh, Kecamatan Karawang Barat. Tinggalan arkeologi, yakni Kelenteng/
Vihara Shian Jin Kupoh, terletak di tepi pertemuan dua sungai yakni Ci Tarum dan Ci Beet, tepatnya di sebelah timur sungai. Jarak antara kelenteng dengan sungai sekitar $75 \mathrm{~m}$. Kelenteng berasal dari tahun 1700-an (abad ke-18). Kelenteng Sian Djin Kupoh merupakan bangunan peribadatan orang-orang Tionghoa, dewa yang dipuja pada kelenteng tersebut ialah Dewa Ma Kupoh.

Di wilayah Tanjungpura juga terdapat beberapa penganjun tembikar atau gerabah, tepatnya di Kampung Anjun Gempol, Kelurahan Tanjung Pura, di Kecamatan Tanjung Pura. Lokasi berada pada ketinggian $29 \mathrm{~m}$ di atas permukaan laut di sebelah timur berjarak kurang lebih 100 m dari Ci Tarum. Kampung Anjun Gempol dahulu merupakan pusat pembuatan wadah tembikar atau gerabah, hampir seluruh penduduk kampung tersebut bermatapencaharian sebagai penganjun. Akan tetapi, saat ini jumlah penganjun berkurang.

\section{Situs-Situs di Tepi Muara Sungai, Tepi Pantai}

\section{Situs Pantai Pasir Putih}

Pantai Pasir Putih termasuk wilayah Desa Sukajaya, Kecamatan Cilamaya Kulon, merupakan pantai dengan posisi berada di bagian timur dari kawasan pantai utara Karawang. Memiliki ciriciri pantai yang landai, terbuka, tempat bermuaranya Sungai Pasir Putih, muara sungai landai, dan dangkal. Nama Pasir Putih bermula dari pasir pantai yang berwarna agak putih disebabkan oleh kerang dan juga terumbu karang yang tergerus. 


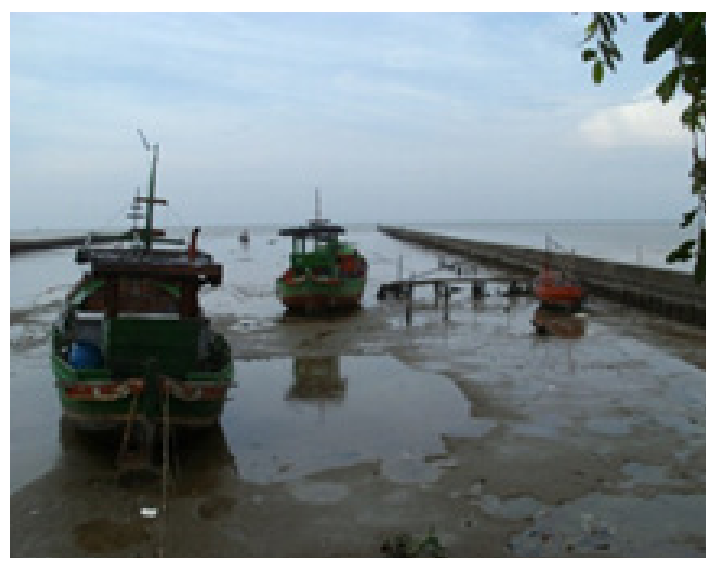

Gambar 3. Pantai Pasir Putih dan dermaganya. (Sumber: Dokumen Pusat Arkeologi Nasional, 2011)

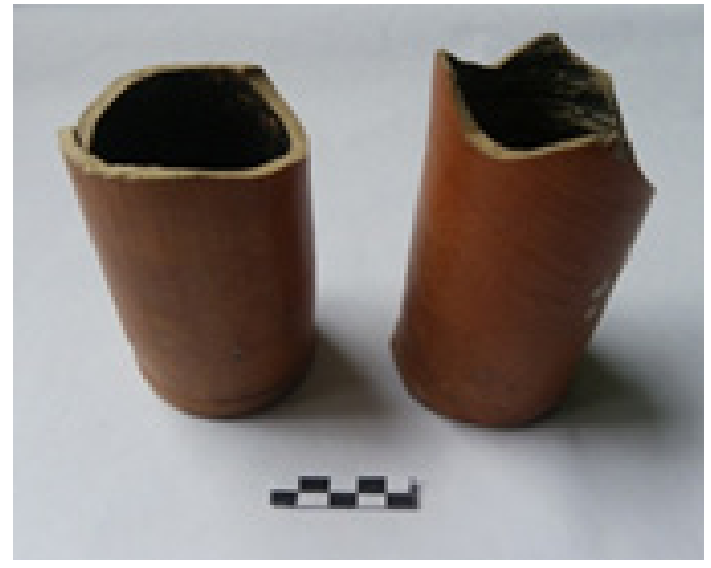

Gambar 4. Botol stone ware Eropa dari Pantai Putih. (Sumber: Dokumen Pusat Arkeologi Nasional, 2011)

Tinggalan-tinggalan arkeologi ditemukan ketika dilakukan pengerukan muara Sungai Pasir Putih pada tahun 1997. Sejumlah tinggalan arkeologi bercampur dengan lumpur dan pasir dari dasar muara sungai ikut serta terangkat ke permukaan, di antaranya pecahan keramik berbagai bentuk mangkuk, mata uang logam Belanda, botol Eropa dari bahan stone ware, dan kaca, dan lampu kapal atau lentera kapal. Saat ini pantai Pasir Putih digunakan sebagai dermaga kapal-kapal nelayan yang berlabuh setelah mencari ikan, dikenal dengan Pelabuhan Cilamaya. Lingkungan sekitar pantai merupakan pemukiman nelayan, selain sebagai nelayan warga juga bermatapencaharian sebagai pembuat perahu.

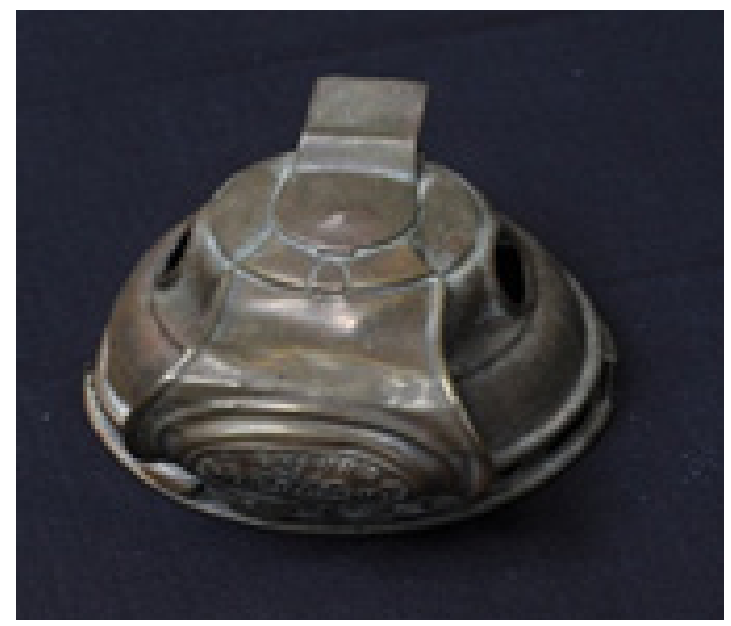

Gambar 5. Bagian dari lampu (lentera) kapal, dari Pantai Pasir Putih. (Sumber: Dokumen Pusat Arkeologi Nasional, 2011)

\section{Situs Tangkolak}

Situs Tangkolak berada di Desa Sukakerta, Kecamatan Cilamaya Wetan, posisi sebelah timur Pantai Pasir Putih. Situs terletak pada muara Sungai Tangkolak di pantai tepi Laut Jawa, potensi arkeologi yang ditemukan berasal dari dalam laut sehingga dikategorikan situs bawah air. Muara Sungai Tangkolak merupakan muara sungai yang terbuka, tidak tertutup oleh tanaman. Laut sekitar muara Sungai Tangkolak tergolong landai dan dangkal kedalaman lebih kurang sama dengan ukuran dada orang dewasa. Sungai Tangkolak ini dapat dilayari oleh perahu-perahu nelayan. Tidak banyak ditemukan tinggalan arkeologi pada permukaan tanah di sekitar muara sungai. 
Tinggalan arkeologi yang ditemukan merupakan temuan yang berasal dari bawah laut berupa keramik baik utuh maupun pecahan yang didapat oleh nelayan karena tersangkut oleh jaring ikan dan aktivitas menyelam di dasar laut. Nelayan-nelayan kadang kala menyelam hingga jarak sekitar 12 mil dari muara

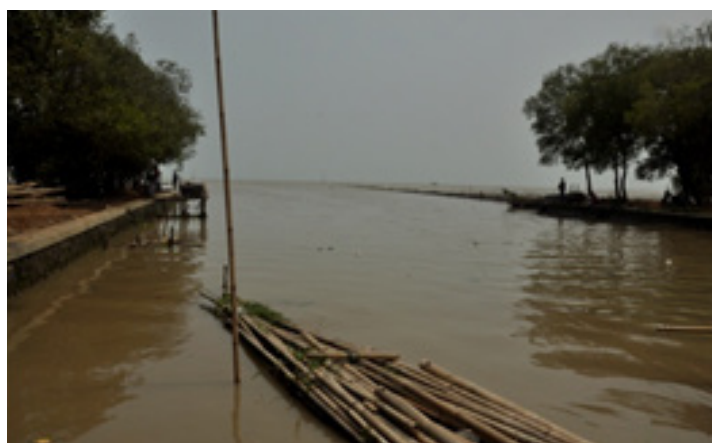

Sungai Tangkolak untuk mencari bendabenda di bawah laut. Beberapa tinggalan arkeologi yang ditemukan dari kegiatan menyelam adalah meriam, balok kayu, dan keramik. Meriam berjumlah dua buah saat ini disimpan di Museum Situs Batujaya.

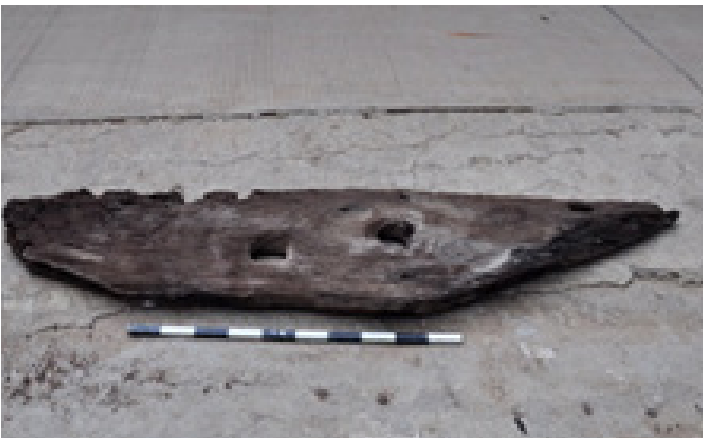

Gambar 6. Muara Sungai Tangkolak dan potongan kayu dari dalam laut pantai Tangkolak. (Sumber: Dokumen Pusat Arkeologi Nasional, 2015 dan 2013)

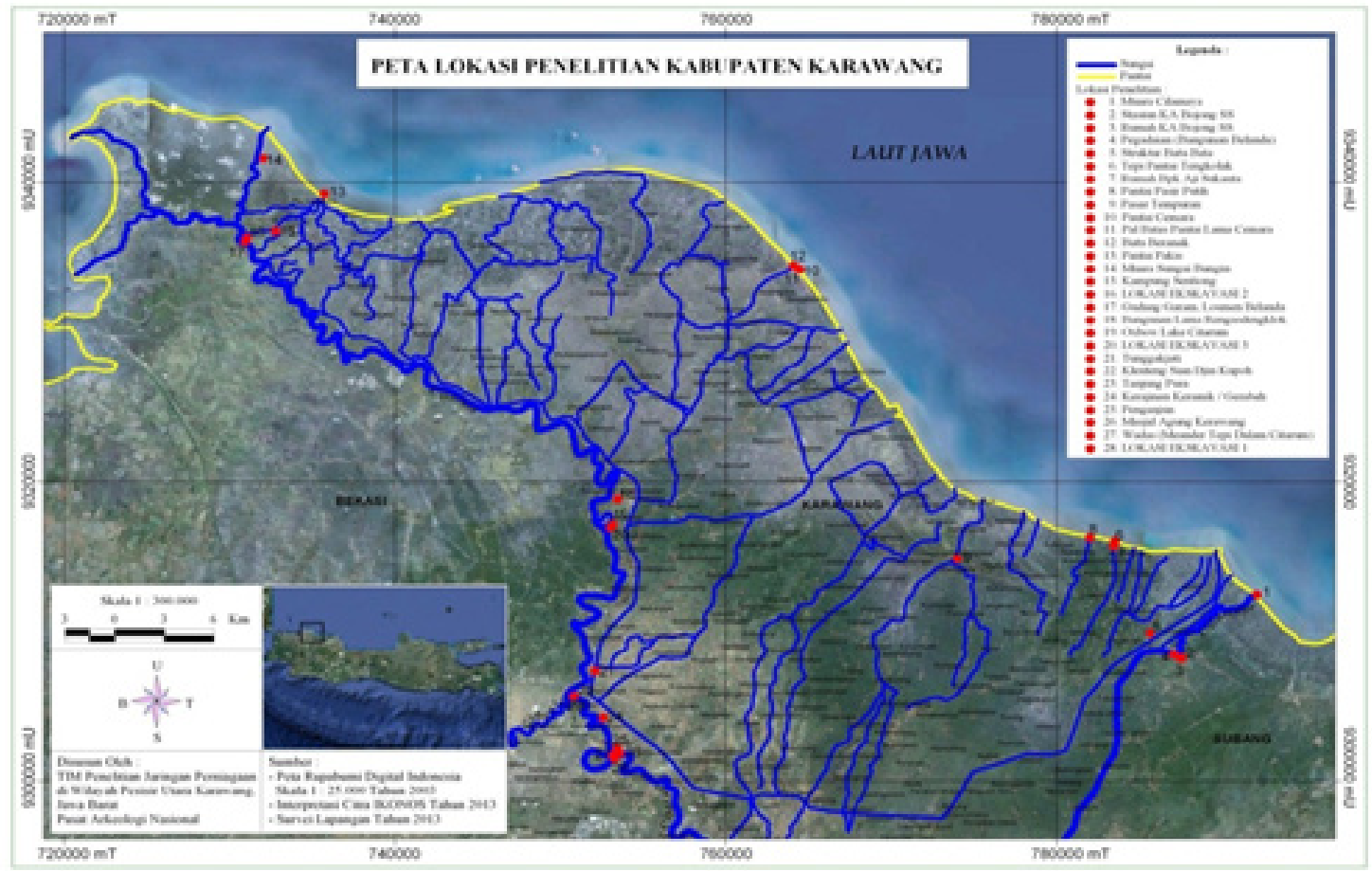

Gambar 7. Situs-Situs di tepi Ci Tarum, tepi muara Sungai Pasir Putih, dan tepi muara Sungai Tangkolak (tanda bulat merah) di Kab. Karawang. (Sumber: Google dimodifikasi) 
Hasil survei pada lima situs yang telah diuraikan, yakni (1) Situs Kedawung, (2) Situs Bunut, (3) Situs Tanjungmekar, (4) Situs Pantai Pasir Putih, dan (5) Situs Tangkolak, berdasarkan ekologinya keseluruhan diidentifikasi sebagai situs yang menempati kawasan perairan di tepi Ci Tarum, tepi muara Ci Tarum, dan pantai tepi Laut Jawa. Sungai, muara sungai, dan pantai yang telah diuraikan teridentifikasi sebagai kawasan perairan yang penting. Situs-situs tersebut secara geografis keletakannya menempati posisi geografis Karawang di bagian utara dan bagian tengah. Seperti diketahui bentang alam wilayah Karawang secara umum dapat dibedakan menjadi tiga bagian, yakni bagian utara, bagian tengah, dan bagian selatan. Bagian utara adalah daerah pesisir sekitar pantai berupa dataran rendah. Pantai utara Karawang bagian tengah adalah dataran rendah dan sebagian bukit-bukit. Adapun bagian selatan daerah berbukit-bukit yang merupakan kawasan pegunungan Sanggabuwana (Tim Penelitian, 2015: 14).

Posisi wilayah Karawang dikelilingi oleh perairan yakni Ci Tarum dan $\mathrm{Ci}$ Lamaya serta Laut Jawa. Sungai-sungai tersebut merupakan batas alam yang memisahkan Karawang dengan wilayah lainnya. Ci Tarum berada di bagian barat merupakan batas antara Karawang dengan Kabupaten Bekasi, Ci Lamaya berada di bagian timur batas antara Karawang dengan Kabupaten Subang. Dua sungai tersebut mengalir ke arah utara. Selain dua sungai besar yang berada di bagian barat dan timur, terdapat pula sungaisungai lain lebih kecil merupakan anakanak dari Ci Tarum, antara lain Ci Beet yang mengalir di bagian tengah wilayah Karawang. Laut Jawa terhampar di sebelah utara Karawang yang merupakan akhir dari berbagai aliran sungai (muara) yang terdapat di Karawang. Pantai utara Karawang merupakan lokasi muara beberapa sungai, di antaranya muara Ci Tarum, Sungai Pasir Putih, Sungai Tangkolak, dan Ci Lamaya. Ci Tarum dan Ci Lamaya tergolong stadia tua (old river stadium). Ciri-cirinya, antara lain aliran sungai berkelok-kelok (meander) dan sangat tenang, sudah tidak dijumpai adanya air terjun sepanjang aliran sungai, erosi horizontal lebih kuat dari pada erosi vertikal, lembahnya agak tumpul dan lebar serta berbentuk huruf "U", dan memiliki pulau-pulau tapal kuda (oxbow lake) (Tim Penelitian, 2015: 13-14). Perkembangan aliran sungaisungai tersebut cenderung mengalami pendangkalan akibat penumpukan lumpur yang terbawa arus air sungai dari bagian hulu, selain itu sungai mengalami penyempitan.

Wilayah-wilayah perairan di pantai utara Jawa bagian barat dan pelabuhan kuna di Karawang abad ke-16 telah diberitakan oleh orang-orang Portugis, yakni de Barros dan Tome Pires, sebagai bagian dari penggambaran mereka tentang wilayah di kepulauan Nusantara ketika itu. Karawang sebagai pelabuhan telah diberitakan oleh de Barros pada abad ke-16 dengan nama Caravam. Penyebutan itu berkaitan dengan nama enam pelabuhan Kerajaan Sunda di pantai utara Jawa bagian barat yang diurutkan dari arah timur menuju ke barat. Pelabuhan-pelabuhan tersebut terdiri dari Chiamao, Xacatra (Caravam), Tangaram, Cheguide, Pondang, dan 
Bantam. Nama-nama pelabuhan tersebut secara berurutan yang dimaksud ialah Cimanuk, Karawang, Tangerang, Cigede, Pontang, dan Banten. Antara Caravam dan Xacatra keduanya berada pada kedua sisi sungai yang berbeda (Guillot, 1992: 15; Djajadiningrat, 1983: 83).

Nama-nama pelabuhan kuna pantai utara Jawa bagian barat juga disebutkan oleh Tome Pires. Agak berbeda dengan de Barros, Tome Pires memberitakan adanya pelabuhan-pelabuhan namun diurutkan dari arah yang berlawanan yakni dari barat ke timur yakni Bantam, Pontang, Cheguide, Tamgara, dan Calapa (Cortesao,1944: 172).

Pelabuhan dalam tulisan ini dimaksudkan sebagai tempat kapal dapat berlabuh dengan aman, terlindung dari ombak besar dan angin. Dalam hal ini unsur lingkungan fisik dipandang sebagai faktor penentu letak pelabuhan. Faktorfaktor alamiah penting, karena teknologi pada waktu itu belum mampu mengatasi kesulitan geografi dan iklim di antaranya batu karang dan angin musim, merupakan rintangan besar pada pelabuhan. Sungai dan muara sungai merupakan tempat yang paling baik untuk pelabuhan. Letak sungai ke dalam jauh dari laut terlindung dari ombak. Adapun muara sungai meskipun di tepi laut namun karena tempatnya agak terbuka baik juga untuk pelabuhan terutama pada teluk (Tjandrasasmita, 1990: 153-157; Lapian, 2008: 95-96).

Merujuk pada lingkungan sebagai persyaratan seperti yang dimaksud, wilayah Karawang terutama bagian utara merupakan ekologi yang mendukung untuk tempat berlabuh atau merapatnya kapal.
Ci Tarum dan Ci Lamaya memungkinkan sekali dilayari oleh kapal, karena sungai tersebut lebar, namun perkembangan hingga saat ini sungai tersebut mengalami pendangkalan dan penyempitan. Pada kenyataannya kapal, perahu, sampan tahun 2013 masih banyak yang hillir mudik di Ci Tarum khususnya sekitar muara dan juga $\mathrm{Ci}$ Lamaya. Kedalaman muara Ci Lamaya sedada orang dewasa. Kapal-kapal nelayan dapat berlayar hingga ke muara. Ilustrasi berikut ini berupa foto kuna sebuah kapal uap (kapal api) yang melintas di Ci Tarum pada tahun 1910, kiranya memberikan gambaran wilayah perairan Karawang sekitar $\mathrm{Ci}$ Tarum merupakan wilayah yang dilintasi oleh kapal.

Menurut R. Bintarto pelabuhan memiliki tiga arti, yakni arti ekonomis, pelabuhan sebagai tempat ekspor-impor dan kegiatan ekonomi lainnya; arti budaya pelabuhan sebagai tempat pertemuan berbagai kebudayaan yang dibawa oleh para saudagar; dan arti politis, karena pelabuhan memiliki potensi ekonomi dan menjadi urat nadi perekonomian negara maka harus dipertahankan keberadaannya (Pardjoko dan Utomo, 2013: 10). Pada kenyataannya situs-situs yang diuraikan tersebut bukan hanya tempat merapatnya kapal, tetapi juga tempat berlangsungnya kegiatan ekonomi dan tempat bertemunya kebudayaan, seperti pendapat Bintarto tersebut. Arti ekonomis terlihat pada Situs Kedawung. Selain tempat merapatnya kapal, keluar masuk barang perdagangan, dan pemungutan bea komoditas, juga tempat kegiatan ekonomi yakni jual beli komoditas berlangsung di Pasar Tanjungbungin. Arti budaya dapat diamati pada Situs Tanjungmekar. Situs tersebut 
selain sebagai tempat merapatnya kapal orang-orang Cina juga tempat tumbuh kembangnya kebudayaan yang dibawa oleh orang-orang Cina yang disebabkan mereka bermukim di sekitar pelabuhan. Budaya tersebut di antaranya adalah bangunan tempat peribadatan orangorang Cina dan perayaan atau keramaian oleh orang-orang Cina menggunakan perahu di Ci Tarum.

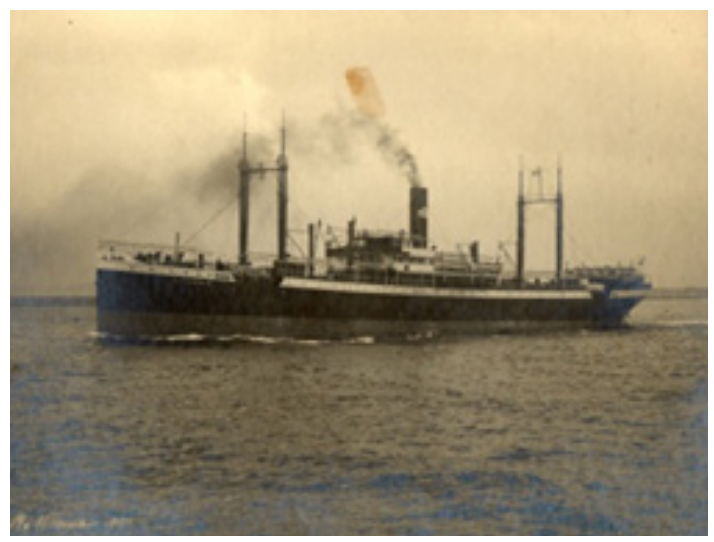

Gambar 8. Sebuah kapal uap melintas di Ci Tarum tahun 1910. (Sumber: http://media-kitlv.nl)

Situs-situs di wilayah perairan Karawang yang telah diteliti berada pada jalur pelayaran lintas pantai utara Jawa bagian barat. Ramainya pelayaran antara Jepara (sebagai pelabuhan Mataram)-Cirebon-Karawang-Batavia sejak abad ke-16 yang terus berlanjut hingga awal abad ke-20, menyebabkan pantai di Karawang sebagai tempat persinggahan baik kapal dagang maupun kapal patroli dan terbentuk pula jejaring antara wilayah pesisir dengan wilayah pedalaman Karawang yang terhubung melalui sungai-sungai. Tanjungbungin tepi Ci Tarum dulu merupakan tempat merapat atau pemberhentian sampan atau perahu dan kapal pengangkut berbagai komoditas dari luar dan hendak menuju ke Karawang. Dermaga sebagai tempat pemberhentian atau tempat merapatnya kapal berada di tepi $\mathrm{Ci}$ Tarum. Tanjungbungin menghubungkan antara daerah pesisir di bagian utara Karawang dengan daerah pedalaman Karawang yang berada di bagian selatan. Tanjungbungin juga pusat perniagaan komoditas perdagangan, ikan laut, beras, garam, dan kayu. Ikan berasal dari daerah pantai di Pakisjaya, beras dari daerah Batujaya, garam didatangkan dari Madura dan disimpan di gudang, kayu didatangkan dari wilayah pedalaman Karawang di bagian selatan. Pengangkutan berbagai macam komoditas perdagangan melalui $\mathrm{Ci}$ Tarum. Aliran Ci Tarum dari arah hulu di bagian selatan menuju ke arah hilir (muara) di bagian utara menuju Laut Jawa. Sebelum menuju ke muara aliran sungai berbelok ke arah barat, ke Muara Gembong di Bekasi. Komoditas perdagangan yang didatangkan dari luar dan hendak diperdagangkan di Tanjungbungin dikenai bea masuk yang dipungut oleh syahbandar di pabean atau duane.

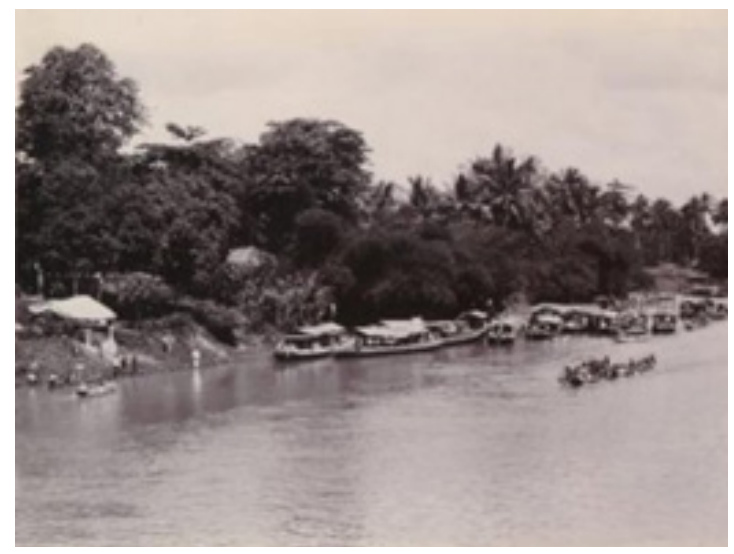

Gambar 9. Perayaan oleh orang-orang Cina di Ci Tarum tahun 1910. (Sumber: http://media-kitlv.nl) 
Nama Ujung Karawang dan Teluk Karawang juga muncul pada abad ke-17. Nama-nama tersebut merupakan daerah patroli (pengawasan, pengintaian), baik oleh VOC maupun Mataram pada abad ke-17, ketika antara Vereenigde Oostindische Compagnie (VOC) terjadi konflik dengan Mataram dan Mataram menyerang VOC di Batavia. Disebutkan pula nama Sungai Craoan (Karawang). Ci Tarum di Karawang merupakan batas wilayah antara VOC di Batavia dengan Mataram pada abad ke-17. Wilayah sebelah barat Ci Tarum menjadi kekuasaan VOC sedang wilayah sebelah timurnya adalah kekuasaan Mataram. Daerah perairan Karawang abad ke-17 merupakan daerah yang diperebutkan antara VOC yang berpusat di Batavia dengan Kerajaan Mataram yang berada di pedalaman Jawa bagian tengah. Kedua kekuatan tersebut terjadi konflik terutama Mataram pada masa Sultan Agung dan masa-masa sesudahnya. Mataram berkepentingan untuk mempeluas wilayah kekuasaan terutama daerah pantai utara Jawa. VOC berkepentingan untuk menguasai Karawang sebagai upaya memperluas wilayah kekuasaannya dan pintu masuk untuk menuju wilayah-wilayah di pantai utara Jawa belahan timur seperti Jepara (Graaf, 1987: 106; 2002: 224226, 231).

Nama Ujung Karawang dengan nama Tanjungbungin keduanya memiliki makna yang hampir sama, yakni daratan yang menjorok ke tengah laut atau semenanjung. Biasanya semenanjung merupakan daratan yang paling mudah terlihat oleh pelaut sehingga menjadi awal tempat bersinggahnya kapal.
Satu-satunya tempat di Karawang yang berlokasi di ujung (semenanjung) adalah Tanjungbungin. Apabila mengamati toponimi Tanjungbungin dan Ujung Karawang serta potensi arkeologi, kiranya dari ciri-ciri tersebut Situs Kedawung di Tanjungbungin dapat ditafsirkan sebagai tempat bersinggah atau berlabuhnya kapal-kapal patroli VOC dan Mataram pada abad ke-17. Sebagai daerah patroli atau pengawasan maka pantai utara Karawang menjadi ramai dan dengan demikian aktivitas perdagangan di pantai utara Karawang ikut bertambah ramai pula. Lalu-lintas perdagangan antara pelabuhan Mataram dan Batavia pun ramai, baik orang-orang Mataram maupun penduduk Batavia mendapatkan keuntungan (Graaf, 2002: 224-226, 231, 267).

Karawang sebagai daerah patroli dan pengintaian dua kekuatan untuk saling mengawasi di antara keduanya. Sebagai daerah patroli atau pengawasan maka pantai utara Karawang menjadi ramai dan demikian halnya aktivitas perdagangan di pantai utara Karawang ikut bertambah ramai pula. Lalu-lintas perdagangan antara pelabuhan Mataram dan Batavia ramai, baik orang-orang Mataram maupun penduduk Batavia mendapatkan keuntungan. Kepala perdagangan Kompeni Belanda Jan Coen dengan Kapal Het Wapen van Delft berjaga di sekitar Karawang (Graaf, 2002: 224-226, 231, 267).

Pelayaran perdagangan di pesisir utara Laut Jawa bagian barat bukan hanya aktivitas pelayaran perdagangan namun juga pelayaran untuk penyebaran 
agama Islam. Pusat penyebarannya berada di Cirebon. Situs Bunut tempat lokasi Masjid Syekh Quro tepat di tepi $\mathrm{Ci}$ Tarum, arti pentingnya sebagai tempat merapatnya kapal Syekh Quro yang bernama lengkap Syekh Hasanudin bin Yusuf Sidik tahun 1418 $\mathrm{M}$ atau abad ke-15. Peristiwa datangnya ulama berasal dari Muara Jati, Cirebon tahun 1418 tersebut bersama dengan perahu dagang, berlayar dari Cirebon ke arah barat menuju Karawang, di sana mendirikan pesantren dan dikenal dengan nama Syekh Quro (Sunardjo, 1983: 18-19).

Di antara seluruh pantai yang terdapat di Karawang, Pantai Pasir Putih dan Pantai Tangkolak, merupakan dua pantai yang teridentifikasi memiliki potensi arkeologi dibandingkan dengan pantai-pantai lainnya. Pantai Pasir Putih merupakan pantai yang landai atau datar bukan jenis pantai yang curam, pantai terbuka tidak tertutup oleh vegetasi sehingga pandangan mata dari pantai menuju arah laut jelas terlihat. Sungai Pasir Putih dan muara sungainya yang mengalir di pantai Pasir Putih memberi kemudahan proses masuk keluarnya kapal dari sungai menuju ke laut dan sebaliknya. Saat ini pelabuhan yang terdapat di pantai Pasir Putih adalah pelabuhan Cilamaya tempat merapatnya kapal-kapal nelayan. Pelabuhan tersebut direncanakan akan dikembangkan menjadi pelabuhan besar untuk kapalkapal pengangkut hasil industri dari Karawang.

Pantai Tangkolak terletak di sebelah timur pantai Pasir Putih, di pantai ini mengalir sungai dan muara Sungai Tangkolak. Pantai Tangkolak landai dan dangkal. Tinggalan arkeologi yang ditemukan adalah temuan berasal dari bawah laut. Potongan kayu merupakan satu jenis artefak yang ditemukan dari bawah laut. Hasil analisis pertanggalan dari Pusat Survei Geologi, Kementerian Energi Sumber Daya Mineral di Bandung, diketahui bahwa potongan kayu yang ditemukan berasal dari abad ke-13 (Inagurasi dkk., 2013: 30). Mengamati ciri-ciri keletakan dan bentuk pantai yang landai, tidak curam, juga ombak laut yang tidak tinggi, serta tinggalan arkeologi seperti bagian lampu kapal abad ke-19, ditafsirkan pantai-pantai tersebut dulu merupakan jalur pelayaran di pantai utara Jawa bagian barat dan tempat merapat atau berlabuhnya kapal. Akan tetapi, jenis kapal belum diketahui.

Pelabuhan-pelabuhan kuna di Karawang dipandang sebagai tempattempat penting bukan hanya sebatas tempat persinggahan atau pendaratan kapal, perahu, namun lebih dari itu yakni sebagai jalur transportasi kuna melalui laut dan sungai dan jalur masuk dari luar wilayah Karawang. Selain itu, pelabuhan-pelabuhan kuna Karawang merupakan cikal bakal tumbuh dan berkembangnya wilayah Karawang. Perkembangan Karawang berawal dari pelabuhan-pelabuhan kuna di tepi muara sungai dan tepi sungai. Awalnya merupakan sebuah tempat pendaratan kapal, sampan, perahu, perlahan-lahan berkembang menjadi permukiman yang luas di tepi muara sungai, tepi sungai. 
Antara pelabuhan yang satu dengan lainnya terintegrasi dan terbentuklah pemukiman yang lebih besar di antara Ci Tarum, Ci Lamaya, dan Laut Jawa. Cirebon memandang penting Karawang sebagai tempat penyebaran Islam di wilayah tersebut. Sementara Batavia juga memandang penting Karawang, sebagai pembatas wilayah Batavia di sebelah timur. Memperhatikan data arkeologi yang telah dikumpulkan menunjukkan periodisasi dari abad ke-15 hingga ke-19, ditafsirkan bahwa pelabuhan-pelabuhan kuna di tepi muara sungai dan tepi sungai Karawang tumbuh berkembang pada periode tersebut.

\section{SIMPULAN}

Setelahmelaluideskripsidata, analisis, dan interpretasi, terhadap tinggalan arkeologi, sejarah, dan lingkungan alam yang ditemukan pada situs-situs di perairan Karawang Jawa Barat, berikut ini dikemukakan simpulan sebagai berikut. Pertumbuhan pelabuhan-pelabuhan di Karawang dipengaruhi oleh faktor ekologi. Perairan yang mengelilinginya, mendukung terbentuknya pelabuhanpelabuhan yang terdapat di pantai utara Karawang, tepi sungai serta tepi muara sungai. Faktor lain yang berpengaruh pada terbentuknya pelabuhan kuna di Karawang ialah kesibukan aktivitas pelayaran pedagangan dan penyebaran Islam di pantai utara Jawa bagian barat, dan interaksi yang berlangsung antara Jawa bagian tengah dan Jawa bagian barat, yang masa puncaknya berlngsung antara abad ke-15 hingga abad ke-19. Keberadaan pelabuhan ditunjukkan oleh adanya jejak-jejak arkeologi dan pemukiman kuna di tepi pantai, tepi sungai, tepi muara sungai merupakan jejak-jejak pelayaran perdagangan di pesisir utara Karawang bagian dari jalur pelayaran perdagangan di pantai utara Jawa bagian barat. Pesisir utara Karawang memiliki muara-muara sungai sebagai pelabuhan tempat merapatnya kapal dagang dan merupakan pintu masuk menuju ke bagian pedalaman.

Dilihat dari lokasi-lokasinya, terdapat dua macam pelabuhan kuna di Karawang, yakni pelabuhan berada di tepi sungai jauh dari laut dan di tepi muara sungai pertemuan antara sungai dan laut. Termasuk kategori pelabuhan sungai adalah Kedawung, Bunut, dan Tanjungmekar. Adapun kategori pelabuhan muara sungai adalah Pasir Putih yang saat ini dinamakan juga dengan pelabuhan Cilamaya dan pelabuhan Tangkolak. Kondisi pelabuhan-pelabuhan pada saat ini bermacam-macam. Sebagian tidak digunakan sebagai pelabuhan yakni Bunut dan Tanjungmekar dan ada pula yang masih digunakan sebagai dermaga kapal-kapal nelayan dan dermaga perahu penyeberangan yakni Pasir Putih dan Tangkolak. Di antara sejumlah Situssitus yang telah diteliti pada tulisan ini di antaranya diduga terdapat Caravam (Karawang) nama pelabuhan di pantai utara Jawa bagian barat yang disebut oleh de Barros pada abad ke-16. 


\section{DAFTAR PUSTAKA}

Cortesao, Armando. 1944. The Suma Oriental of Tome Pires an Account of The Red Sea to Japan, Written in Malacca and India in 1512-1515. London: Hakluyt Society.

Djafar, Hasan. 2010. Kompleks Percandian Batujaya: Rekonstruksi Sejarah Kebudayaan Daerah Pantai Utara Jawa Barat. Bandung: Kiblat Buku Utama.

Djajadiningrat, Hoesein. 1983. Tinjauan Kritis tentang Sajarah Banten. Djakarta: Djambatan.

Graaf, H.J. de. 1987. Disintegrasi Mataram di Bawah Mangkurat I. Jakarta: Grafitipers \& Koninklijk Instituut Voor Taal Land En Volkenkund (KITLV).

Graaf, H.J. de. 2002. Puncak Kekuasaan Mataram Politik Ekspansi Sultan Agung. Jakarta: Grafitipers \& Koninklijk Instituut Voor Taal Land En Volkenkund (KITLV).

Guillot, C. 1992. Perjanjian dan Masalah Perjanjian Antara Portugis dan Sunda Tahun 1522. Aspek-Aspek Arkeologi Indonesia, 13. Jakarta: Pusat Arkeologi Nasional.

Inagurasi, Libra Hari, dkk. 2013. Jaringan Perniagaan di Pantai Utara Karawang, Jawa Barat. Laporan Hasil Penelitian Arkeologi. Jakarta: Pusat Penelitian Arkeologi Nasional.

Lapian, Adrian B. 2008. Pelayaran dan Perniagaan Nusantara Abad ke-16 dan 17. Jakarta: Komunitas Bambu.

Nastiti, Titi Surti, dkk. 2011. Penelitian Pantai Utara Jawa Barat, Kabupaten Bekasi dan Karawang, Provinsi Jawa Barat. Laporan Hasil Penelitian Arkeologi. Jakarta: Pusat Penelitian dan Pengembangan Arkeologi Nasional.

Pardjoko, Didik dan Utomo, Bambang Budi. 2013. Atlas Pelabuhan-Pelabuhan Bersejarah di Indonesia. Jakarta: Direktorat Sejarah dan Nilai Budaya, Direktorat Jendral Kebudayaan, Kementerian Pendidikan dan Kebudayaan.

Sunardjo, R.H. Unang. 1983. Meninjau Sepintas Panggung Sejarah Pemerintahan Kerajaan Cerbon 1479-1809. Bandung: Tarsito.

Tim Penelitian. 2015. Karawang dalam Lintasan Peradaban. Laporan Hasil Penelitian Arkeologi. Jakarta: Pusat Arkeologi Nasional. 
Tim Penyusun. 2009. Awal Peradaban di Pantai Utara Jawa Barat Kompleks Percandian Batujaya, Karawang. Laporan Hasil Penelitian Arkeologi. Jakarta: Pusat Penelitian dan Pengembangan Arkeologi Nasional.

Tjandrasasmita, Uka (Editor). 1990. Sejarah Nasional Indonesia III. Jakarta: Departemen Pendidikan dan Kebudayaan. 